\title{
Socio-cultural integration in the youth environment: the high school experience
}

\author{
Vera Makedonskaja ${ }^{1}$, Galina Bykovskaia $^{2}$, and Elena Miroshnichenko ${ }^{3, *}$ \\ ${ }^{1}$ Moscow Engineering Physics Institute, 115409, Kashirskoje Shosse, 31, Moskow, Russia \\ ${ }^{2}$ Federal State Budgetary Educational Institution of Higher Education "Voronezh State University of \\ Engineering Technologies", 394036, Revolution Avenue, 19, Voronezh, Russia \\ ${ }^{3}$ FSBEI Voronezh State University of Engineering Technologies, 394036, Revolution Avenue, 19, \\ Voronezh, Russia
}

\begin{abstract}
The priority directions of the spiritual and moral components of the personality formation are characterized in the article, the effectiveness of the program of conducting educational events at different levels with the higher education students' participation is being investigated. In the article it is proved that a harmonious system of educational work has been formed in the universities of Russia, including the Voronezh State University of Engineering Technologies and the Moscow Engineering Physics Institute, within the framework of which a process of sociocultural integration of student youth is being introduced, not only by Russians of different nationalities, but by the representatives of other countries and continents. In this context, the role of the Youth Innovation Forums ("MIF") held annually on the basis of VGUIT in the Voronezh region is head lighted, which reached the regional level and included in its orbit not only students but also schoolchildren. The article presents the project of the educational program of the Moscow Engineering Physics Institute with emphasis on the Orthodox value use.
\end{abstract}

\section{Introduction}

In January 2016, the National Security Strategy was amended. Among the priority tasks in the sphere of science, technology, education and culture, there were named such tasks as "System improving of supporting talented children, additional education", "Creating a system of spiritual, moral and patriotic education of citizens". In other words, the state assumes the responsibility for the formation and financial support of educational and brining up sphere. The interest of the power to the education problems is quite logical. Meanwhile, ignorance, consumer conformism, manifesting itself in the mass consciousness are antipodes of patriotism and favorable environment for the destructive processes growth and social upheavals. St. Petersburg's scientists S.Yu. Kargapoltsev and I.Yu. Lapina in this connection call the pain points of the modern educational process [1-10,11, p.334-336]:

\footnotetext{
* Corresponding author: emirosh79@gmail.com
} 
1. Quality deterioration of the school leavers training. State Exam, at the same time, provokes these processes, as it requires not understanding, but drilling the material. Today at schools they don't teach to think, but train to pass tests.

2. In the student environment, the main goal is not the process of obtaining knowledge, but the surrender of current sessions and diploma getting, that is, not "serving the cause", but realizing career-commercial interests.

3. The commercialization of the educational process and education financing on a residual basis lead to underestimation of the humanitarian disciplines. The ignorance of important dates, bright names and significant events meaning in our history to be a usual practice.

Today it is clear that the achievement of the goal of educating a harmoniously developed, active personality, a professional is accomplished through solving the problems of forming general cultural competence for a specialist. General cultural competences are conditionally divided into the competence of a person in the sphere of his ideas and his interaction with the surrounding natural and man-made world; the competence of the social culture interaction; competence of activity culture; competence of personal (internal) culture. The solution of such complex tasks is possible only with the unification of university teachers' forces in all directions. But this association is not possible on every educational platform.

\section{Problem Statement}

Technological challenges of the XXI century require highly educated specialists, engineers capable of integration traditional production and information technologies. Modern society needs competitive, creative individuals with a high professional and general cultural level, motivated to self-education throughout all life. The most important component of this process is social and the humanitarian knowledge. Social and humanitarian training in a technical university is designed to form the scientific worldview, the quality of patriotism and citizenship, socially adapt norms of behavior, and constantly improve the general cultural level.

Among the urgent tasks of the 21 st century in the field of education, science and technology, it is necessary to mention the most important thing - to ensure the training of qualified personnel able to assimilate the sum of the accumulated knowledge, necessary to ensure the safety of the use and further development of new technologies and techniques for the future.

\section{Research Questions}

Our education is an indicator of the society development and of those positive changes that are taking place in it. It should be noted that the educational space of each educational institution is unique, while its creation and pedagogical experience development, traditions and innovations are used, the past and future of the educational institution, its history, traditions and development prospects are combined. At its core, the educational space of a higher educational establishment is an author's right. When creating authoring systems of upbringing within the framework of the state standards, special importance is given to the microclimate of the educational institution, as an element of the educational space. K.D. Ushinskiy, speaking about education facts, said: «The spirit of the institution means much, of course; but this spirit does not live in walls, not on paper, but in the nature of most educators and from there already passes into the character of our pupils» [14].

In Voronezh State University of Engineering Technology (further - VSUET) VSUET the content of spiritual and moral education has changed in recent years. So, the field of the 
city conference "Preservation of the national cultural heritage", conducted by the Scientific Library on the basis of VSUET, expands. If earlier the conference platform united representatives of the city's libraries, now many teachers, students, local historians, scientists are participating in it [4, p. 28-33].

Military-patriotic education included previously ineffective forms of work, such as the exhibition "Victory Posters", "VSUET in 1941". Expositions are prepared together with the museum's director, university historians and their students. VSUET teachers actively work with the regional council of regional studies. The conferences of Voronezh regional specialists in 2016-17 were held on the basis of the University of Engineering Technologies. The problems of local history proved to be close not only to the humanities, but also to specialists of technical faculties. That is why the international scientific and practical conference "Voronezh Region in Peter IEpoch" included the speeches of Doctor of Historical Sciences G.A. Bykovskaia and Doctors of Technical Sciences S.V. Shakhov, L.E. Glagoleva.

One of the main roles in the spiritual values development of Russian people is played by both the educational environment and volunteer associations [10]. This sphere begins its impact already from kindergarten and continues at schools and higher educational institutions. At present, the programs of spiritual development of students of higher educational institutions of Russia are in active demand within the framework of the state youth program "Territory of Meanings". The participants of the All-Russia Forum in Klyazma returned to the university as ready leaders of the youth movement.

One of the forms of communication among the youth community is round tables. VSUET traditionally holds round tables on the topics: "Orthodox Russia: past, present, future"; "The tolerance formation in the youth environment." The Public Chamber of the Voronezh Region actively participates in organizing these very interesting events. The discussion of the problems is in vivid and interesting nature due to the fact that representatives of the national diasporas join it (the Voronezh Georgian community Bagrationi, the National Cultural Autonomy of the Ukrainians, the "Commonwealth of Nations", the public organization "Ellada", the Russian-Belarusian friendship society, and many others) [10], as well as the Coordinating Council of the Caucasus' Peoples, whose chairman GazibegOmarovichMagomedov is a professor at VSUET.

Dean's office in the search for effective forms of educational work organized roundtables on the problems of extremism prevention and tolerance education of the youth on the basis of VSUET with the participation not only of the Public Chamber of the Voronezh Region, heads of diasporas, the Youth Parliament, but also with the representatives of the Voronezh and Borisoglebskaya Diocese. Professor VSUET Magomedov G.O. (Deputy Chairman of the National Chamber under the Governor of the Voronezh Region), prof. Bykovskaia G.A. (the Head of the Philosophy and History Department), representatives of the dean's office, VSGUIT psychologists are the initiators and coordinators of the events. The round table in 2016 was held, in particular, within the framework of the International Youth Forum "We are the Russians!" with the participation of representatives of Voronezh Region administration.

The international youth festival "Voronezh History Images" is taking place in the format of a round-table complex discussion in Voronezh. The Diploma of the Our History Party was awarded to VSUET student, the head of the media group Elena Volkova for the best work of the regional photo festival "Voronezh History Images" in the nomination "Native Landmarks". The photo festival acquired an international status in 2015, and was held by the university's media group on the basis of VSUET [8]. 
Table 1. Target indicators for the main areas of VSUIT activities [15]

\begin{tabular}{|c|c|c|c|c|c|c|c|c|}
\hline Target indicator / unit of measurement & \multicolumn{7}{|c|}{ Targetvalue } \\
\cline { 2 - 7 } & $\mathbf{2 0 1 6}$ & $\mathbf{2 0 1 7}$ & $\mathbf{2 0 1 8}$ & $\mathbf{2 0 1 9}$ & $\mathbf{2 0 2 0}$ & $\begin{array}{c}\mathbf{2 0 2 1} \\
\text { plan }\end{array}$ \\
\hline \begin{tabular}{c} 
Development direction. Social and educational activities \\
\hline $\begin{array}{c}\text { 1 Number of students participating in the } \\
\text { work of student associations, people }\end{array}$
\end{tabular} & 2500 & 2700 & 2800 & 3100 & 3200 & 3300 \\
\hline $\begin{array}{c}\text { 2 Number of sports events organized by } \\
\text { the university, units }\end{array}$ & 3 & 3 & 4 & 4 & 5 & 5 \\
\hline $\begin{array}{c}\text { 3 The number of cultural and creative } \\
\text { events organized by the university, units }\end{array}$ & 30 & 32 & 34 & 36 & 38 & 40 \\
\hline $\begin{array}{c}\text { 4 Funds aimed at ensuring cultural leisure, } \\
\text { creative and sports development, a } \\
\text { healthy lifestyle for employees and } \\
\text { students of the university, thousand } \\
\text { rubles. }\end{array}$ & 3000 & 3300 & 3500 & 4000 & 4100 & 5000 \\
\hline $\begin{array}{c}\text { 5 The number of students involved in the } \\
\text { volunteer movement, people }\end{array}$ & 100 & 120 & 150 & 1400 & 1400 & 1500 \\
\hline $\begin{array}{c}\text { 6 Participation in city, regional and all- } \\
\text { Russian creative events, units }\end{array}$ & 10 & 10 & 12 & 12 & 15 & 15 \\
\hline $\begin{array}{c}\text { 7 Participation in city, regional and all- } \\
\text { Russian sports events, units }\end{array}$ & 10 & 11 & 12 & 13 & 14 & 15 \\
\hline $\begin{array}{c}\text { 8 The number of young people involved } \\
\text { in the sports life of the university, people. }\end{array}$ & 250 & 300 & 400 & 800 & 1200 & 2000 \\
\hline $\begin{array}{c}\text { 9 Number of sports realized at the } \\
\text { university, units }\end{array}$ & 20 & 25 & 27 & 30 & 32 & 35 \\
\hline
\end{tabular}

The future of Russia is for young energetic and educated people. Even in 2009, as a part of the vectors development of youth policy, the President of the Russian Federation V.V. Putin said: "Those who are 15, 20, 30 years old at the age of 40 will become the main actors in our country in implementing plans and projects for the development of Russia." That is why all those involved in educational work need to unite their efforts to develop programs for the formation of youth tolerant consciousness, patriotism and citizenship in the youth environment.

In Moscow in June 14, 2017, the opening of the First All-Russian Scientific Conference "Theology in the Humanities Educational Space" took place. The purpose of the forum, which was supported by the Ministry of Education and Science of the Russian Federation on the basis of the National Research Nuclear University "MEPhI" and the Church-wide postgraduate and doctoral studies of Saints Cyril and Methodius, is a discussion of actual theoretical and practical problems of the theological branch of knowledge and the development of theological educational programs in modern Russia [14]. The Minister of Education and Science O.Yu. Vasilyeva in her speech at the conference, reported that an order was signed, according to which it is now possible in Russia to award academic degrees of candidates and doctors of theology. The scientific specialty "Theology" appeared in Russia even in 2015, but special theological degrees for theologians were not envisaged. "It seems to me that we need to pay special attention to the scientific personnel training. Therefore, the next question is the strengthening and strengthening of the theology departments, O.Yu. Vasilyeva. According to her, in Russia there are no obstacles for this science area to develop, and this is only the beginning of the road. Recognition of the scientific status of theology corresponds to the modern world experience and the strategy of integrating Russian science into the world scientific community, the chairman of the Department for External Church Relations of the Moscow Patriarchate, the rector of the All-Church Postgraduate and Postgraduate Studies, Metropolitan Hilarion of Volokolamsk, 
said: "But it is important that theology becomes open to public and social problems being solved in our country, and its role in the overall scientific and humanitarian space was fully used for the development of interreligious dialogue and cooperation".

One of the most important events in the spiritual life of Voronezh students was their participation in the Olympiads on spiritual and moral culture. In 2016, the Olympiad was held in the framework of the theme "Athos - the spiritual light of Orthodoxy", in 2018 it was dedicated to Orthodox martyrs. The event was attended by teams from almost all Voronezh universities. Being participants, we note the importance of the event in the personal development and students' spiritual enlightenment. Preparation for the Olympiad forced all participants to rise in their cultural and spiritual development, broaden their horizons. VSUET students independently, through studying the literature of various levels, and with the help of teachers studied the history of Athos, a geographical map, all the accompanying terms, designations, spiritual relics. One of the participants of the Olympiad was the team of Voronezh Orthodox Seminary, who were well prepared due to their profile education and they won the Olympiad. According to this result, it can be judged that VSUET has a powerful base for the youth development and realization in all educational areas. We point out that the main goal of the Olympiad for VSUET students was not a victory that opens the way to the next stage of the Olympiad, but the acquired knowledge, acquired skills, spiritual foundation and, of course, answers to many personal questions with which all the participants of the Olympiad have left.

Since the foundation of the National Research Nuclear University "MEPhI" (further NNIU MEPhI), unique training programs for research engineers have been created at the university. The feature of the University is its status duality. On one hand, the NIIU MEPhI is a state university, guided by the legislation on education and scientific activity. On the other hand, a nuclear facility that trains specialists in critical technologies using nuclear and radioactive materials [1].

In recent years the leadership policy of NRNU MEPhI, headed by the rector M.N. Strikhanov led to the fact that our scientists, having received abroad a unique experience of participating in international scientific projects, return to realize their scientific potential in Russia. Students and graduates of the university participate in international research programs, including research collaborations on the basis of the world's leading scientific centers. Despite certain opposition to the surrounding social environment, the House Temple, consecrated by the Patriarch of Moscow and All Russia Kirill in the name of the Smolensk Icon of the Mother of God, operates under a strictly technical university, the Department of Theology was created and operated successfully headed by Metropolitan Hilarion of Volokolamsk.

In 2010, Holiness Patriarch Kirill consecrated a house church in NIYA MEPhI in honor of the Smolensk Icon of the Mother of God, thereby laying a firm foundation for the interaction of the Church and the University. The temple is the center of a diverse range of activities: from lectures on Orthodoxy to pilgrimage trips and charitable events.

At the present stage of development, a more fundamental study of religious experience is required in all its manifestations: both historically and concerning the life of modern society and culture. This is necessary for Russia's exit from the spiritual crisis in which it found itself [6].

The representatives of the Orthodox Church also face a difficult task - to overcome the stereotypes imposed in the Soviet times, and to realize that secular education and the church, science and religion do not deny each other, but complement each other.

The problem of training future specialists is solely responsible. It concerns the entire Russian society. There are examples of good, mutually respectful cooperation between the Church and the university community. These are the departments of theology in universities, house university temples, interdisciplinary centers, students volunteer 
initiative. All these initiatives should be developed and supported. Knowledge of Christian traditions, the religious way of thinking is necessary for full participation in culture in general, for the European cultural heritage, in particular.

In modern conditions, in connection with the problems of the educational process among students, the need to preserve the continuity of the national spiritual tradition is growing. Today we often talk about the spiritual and moral revival of our society. One of the important factors in the revival of Russia is the cooperation of the state and the Russian Orthodox Church (hereinafter ROC). It is necessary to actualize this unity of purpose, as a free and responsible dialogue. It is not justified to contrast science and religion, reason and faith.

NIIU MEPhI is a special and unique space for the meeting, discussion and fruitful interaction between the Church and society, theology and science, representatives of different views, ready to interact in the development of public thought, preservation of traditions and the fully developed personality formation.

At present, the Cultural and NIIU MEPhI Historical Center "Our Heritage" is implementing the project "Spiritual and moral education of students in a technical university" of the International Open Grant Competition "Orthodox Initiative 2015-2016" (Makedonskaya, 2013). Based on the results of the events held at the NIYA MEPhI, a collection of articles was published of the conference participants "The Role of the Russian Orthodox Church during the Great Patriotic War", May 5, 2016 and there was a competition of student works "Russia Holy Land" (April 20, 2016-20 May 2016) [9].

An important place in the organization of the upbringing process at the university is given to the organization of excursion activities and the introduction of students to the historical and cultural heritage of our country's past. For example, for students of the first year of NNIU MEPhI, excursion and art programs, master classes are conducted by museums in Moscow. Especially close cooperation of the Cultural and Historical Center "Our Heritage" has developed with the Museum-Reserve "Kolomenskoye-IzmailovoLefortovo-Lublino" [12].

Within the framework of the project "Spiritual and moral education of students in a Technical University" of the international open-ended grant competition "Orthodox Initiative -2016", a weekly excursion to the Palace of Tsar Alexis Mikhailovich in Kolomenskoye was planned and implemented, as well as excursions and art programs "An Ambassadorial custom", "Tsar Alexei Mikhailovich and his heritors in Kolomenskoye", etc. [13].

Excursions to Tsaritsyno museum-reserve and the State Historical Museum were realized with constant interest and emotional perception. The students learned many new and interesting facts about the history of the Russian state, about the internal and foreign policies of outstanding statesmen and rulers, about the peculiarities of the mentality of Russian people and about the interaction of the state with the ROC.

It is worth paying special attention to the fact that the Russian education system is closely connected with the educational process. At the same time, the educational space creates the basis for extracurricular activities and the relevance of it. Hence - the need to develop training-methodological complexes (here in after - TMC) of the modern level. Today at the core of the TMC there is a systematic approach that takes into account both the one for all mankind and the special in social processes, forms a holistic vision of history, reflects the change in the forms of social relations, the patterns of the transition of traditional society to the industrial one, then to the information society, emphasizing the problem civilizational identity of Russia. Depending on the distribution of the educational burden of each specific direction, the lecturer varies the subject of lectures, seminars and assignments for independent work. 
The best students scientific research and creative work are sent to interuniversity conferences, competitions (for example, participation in the All-Russia competition of works "My country is my Russia", to the annual Moscow scientific-practical conference "Student Science") [2].

In this context, the most responsible and necessary university course studying is "History". The tendency of increased attention to the issues of the general historical education development is universal in nature and is conditioned, first of all, by the functions of historical education, connected with the formation of the national-civic identity of youth, the role of historical education in the historical memory formation. Understanding the relationship between politics, collective historical memory and the content of historical education is an urgent problem.

The modern approach in teaching history supposes the unity of knowledge, value relationships and students' cognitive activity. The history course has a special potential value for achieving the most important pedagogical results, first of all it is educational and brining up priorities. Unfortunately, the current young generation does not know the history, often does not realize and does not feel themselves as a part of their people and their great country (Makedonskaya, 2015). Therefore, the historical community of Russia faces the task of educating a new generation of creative scientific and technical intelligentsia, aware of Russia's civilizational identity, being proud of it and ready to devote their life to ensuring Russia's technological sovereignty.

\section{Purpose of the Study}

Engineering pedagogy solves the problems of humanizing engineering and technical education and professional training of scientific and technical intelligentsia and teachers of technical disciplines, developing a scientifically based basis and pedagogical technologies that actualize the opportunities for development of spirituality and creative potential of all subjects of engineering and technical activity. New approaches are needed not only to organize educational activities, but also for educational system formation of a university. The sphere of cultural and aesthetic education of students of the Voronezh State University of Engineering Technologies today includes, like in a number of other technical universities of the country, a united course of Professional Ethics, Aesthetics and Culture, the work of the Clubs "Poetic Meetings", sports and discussions. The clubs on interests, groups of photo correspondents (media group VSUET) and "Experts", choreographic and vocal studios, KVN, the People Theatre are very popular. How all these structures form a cohesive youth perspective collective, how effective are the pedagogical methods and educational forms used today-the purpose of our research.

\section{Research Methods}

1. The system-structural method makes it possible to consider the state educational policy as a specific activity of the state with internal structural-content components, to identify the tasks and functions of the "conductors" of the above policy, to analyze the mechanism of their mutual relations.

2. The comparative method is used to identify and to compare the content of the implementation of state-regulated postulates of youth and educational policies implemented at the regional level.

3. The statistical method is necessary while processing quantitative data on the relevance and effectiveness of specific measures for an individual formation that is adequate to the time requirements. 


\section{Findings}

It should be noted that the main characteristics of a graduate of a higher education institution are his general and professional competence, as well as the ability to selfdevelopment. This puts forward new requirements to the methodology for conducting lectures and practical classes in humanitarian disciplines, to organizing independent students' work, the methodology for conducting current, midterm and final control of students' knowledge by teachers. Ultimately, the question raises about the effectiveness of managing student learning activities.

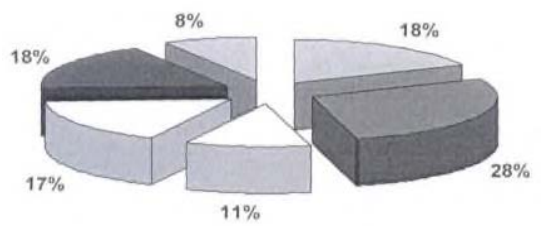

Fig.1. Ratio of program activities

Thus, the percentage of activities in the areas of activity is [16]:

Adaptation of freshmen students $18 \%$

Civil-patriotic education $28 \%$

Moral and aesthetic education 11\%

Formation of a culture of health $17 \%$

Prevention of drug addiction and other addictions $18 \%$

Activation of student self-government $8 \%$.

The motivation of teaching theology in a public educational institution depends on historical traditions. Russia, no matter how we relate to this - is a country with rich Orthodox traditions. It was Orthodoxy that was the core around which much was built in our lives. Today world scientists are studying the scientific heritage of representatives of Russian Orthodox theological science. There is a large number of state and confessional institutions in civilized countries specializing in Christian culture, church history, there are famous libraries, archives, a huge Christian encyclopedic literature. After all, it was the teachings of the church that largely determined the course of history, formed the spiritual appearance of people, the type of statehood.

At the same time, the discipline "History" remains one of the basic, compulsory subjects for study, since it contributes the formation of a number of general cultural competencies that bachelor's degree students should possess.

The era of scientific and technological progress has led to a significant role of higher education institutions in the scientific and engineering training and public-management elite. At the same time, the problem of social competence is directly related to the moral development of future specialists, the establishment of values system that combine freedom of creativity with their professional responsibility. As practice showed, high school content can solve these problems.

The awareness of the obvious truth that without a high level of general culture, a modern engineer is not able to fulfill his professional duties at the level of the 21 st century requirements, was the reason for the expansion and diversification of the content of humanitarian engineering training practically in all countries of the world. Russia, realizing the inevitability of the improvement and modernization prospects, should remain in line with global trends. 


\section{Conclusion}

The creation of a humanitarian environment in a technical university is an important condition for quality improvement of training specialists. The humanitarian educational environment is a combination of the educational process in the humanities and ancillary means: cultural, scientific and mass educational activities. Today we are talking about the need to form a new education system, which must correspond to the current socioeconomic reality. For two decades in our country, along with the transformation of the whole society, the transformation of the higher school has also taken place, having passed several stages from the reform of the 1990s through the process of modernizing century turns to modern innovative features. The purpose of these transformations is to form a new level education system that should help Russia meet the challenges facing in social and economic spheres, ensure national security, strengthen state institutions of power, and facilitate their adaptation to global information sociocultural processes.

We believe that the priorities of higher education in the new socio-economic conditions should be the following: innovations creation through the formation, development and knowledge preservation; integration of the younger generation into a globalized world, the world economic and information space; preparation for active life in a democratic society, creating a foundation for the development of civil responsibility in conditions of choice freedom for each person; ensuring social mobility in society by supporting the most talented youth, entering highly skilled specialists in the labor market; stimulating the need for continuing education to continuously update the knowledge and skills required for professional activities.

The purpose of the University in this context is stuff, scientific and innovative provision of domestic production on the basis of reforming multilevel professional education, ensuring the integration of science, education and production. To achieve this goal, it is necessary to solve a set of interrelated tasks: to modernize the education system at different levels; to develop a system of fundamental scientific research on priority areas of science and technology; form a modern educational and educational innovation environment; modernize the infrastructure of material and technical base.

The reform of humanitarian education in the technical school of Russia is currently expedient to implement in the following areas:

1. Determination the place of each humanitarian and socio-economic disciplines in engineering education;

2. Professional orientation of the humanities education;

3. Improving the methodology and methodology of teaching the humanitarian and socioeconomic sciences, enhancing educational work.

Thus, education is now for the first time seen as a driving force that can significantly change not only its subjects, but also modern society as a whole. Young stuff of scienceintensive branches of innovative Russia are precisely the vanguard that is capable of bringing the domestic economy to new frontiers, creating all the necessary conditions for the prosperity of our country. V.A. Sukhomlinsky wrote: "The homeland is your home, your cradle. In your home, not everything is smooth and everything is not good". A true citizen should understand that nothing will change without his active participation.

The mission of Russia in the 21 st century is to give the world an example of a solidary society in which many people and religions can coexist without a conflict. Only such society is able to contain the "controlled chaos" of the periphery of the economically developed world that was embittered and destroyed as a result of a series of "antiterrorist actions" and the excessive ambitions of superpowers who lost their sense of proportion in their irrepressible striving for global domination, with absolute confidence in their own 
infallibility. Only Russia, but no other country, is capable of such a restraining impulse of power in the modern world.

\section{References}

1. A. Benner, S. Graham, The transition to high school as a developmental process among multiethnic urban youth. Child Development 80 356-376 (2010)

2. G. Bykovskaia, Historical heritage as the basis for the patriotism formation. Modern problems of the humanities and social sciences 1(5), 28 - 33 (2015)

3. G. Bykovskaia, The system of spiritual and moral education of VSUET students Proceedings of the Rostov State University of Communications 1, 37 - 39 (2014)

4. R. Crosnoe, A. Huston, Socioeconomic status, schooling, and the developmental trajectories of adolescents. Developmental Psychology 43, 1097-1110 (2007)

5. B. McCombs, What do we know about learners and learning? The learner-centered framework: Bringing the educational system into balance. Educational Horizons 2001183-193

6. Modern educational technologies and their use in the system of humanitarian training of engineers Materials of the Second All-Russian Scientific and Methodological Conference (Moscow, MSTU named after N.E. Bauman, 2010)

7. D. Orr, Ecological literacy: Education and the transition to a postmodern world (Washington D.C., Island Press, 2012)

8. Patriotic education of students in technical universities: Materials of the III International Scientific and Practical Conference, October 26 76, (Voronezh State. Univ. Engineer. Tech., Voronezh, 2012)

9. Spiritual and moral education of students in a technical college. Collected materials of the conference "The Role of the Russian Orthodox Church during the Great Patriotic War" and the competition of student works "Russia Holy Land ", ed. V. A. Makedonskaya, National Research Nuclear University "MEPhI" NNIU MEPhI 248 (2016)

10. A. Subramaniam, Garden-based learning in basic education: A historical review. $4 \mathrm{H}$ Center for Youth Development, Summer. Retrieved April 2 (2016) http://fourhcyd.ucdavis.edu (Last accessed 14.07.2020)

11. The humanitarian educational environment of the technical university: materials of int. scientific-method Conf 334-336 (Saint-Petersburg, Publishing house of Polytechnic. Un-ty, 2016)

12. The year of Russian history in the technical universities of the country. Materials of the All-Russian Scientific and Practical Conference Moscow, November 13-15, 77 (Moscow, 2012)

13. The Romanovs. Crowned surname (To the 400th anniversary of the House of the Romanovs): Proceedings of the All-Russian Student Scientific and Practical Online Conference, April 15, 2013 (Moscow) National Research Nuclear University "MEPI" Moscow, NIAS MEPI 56 (2013)

14. Theology in the Humanities Educational Space http://wwwpatriarchia.ru/db/text/707952 (Last accessed 18.07.2020)

15. Current archive of the Department of Philosophy and History of Voronezh State University of Engineering Technologies. 
16. Current archive of the Faculty of Humanities Education and Education, Voronezh State University of Engineering Technologies. 